\title{
Observations on the Morphology, Pollination and Cultivation of Coco de Mer (Lodoicea maldivica (J F Gmel.) Pers., Palmae)
}

\author{
Stephen Blackmore, ${ }^{1}$ See-Chung Chin, ${ }^{2}$ Lindsay Chong Seng, ${ }^{3}$ Frieda Christie, ${ }^{1}$ \\ Fiona Inches, ${ }^{1}$ Putri Winda Utami, ${ }^{4}$ Neil Watherston, ${ }^{1}$ and Alexandra H. Wortley ${ }^{1}$ \\ ${ }^{1}$ Royal Botanic Garden Edinburgh, 20a Inverleith Row, Edinburgh EH3 5LR, UK \\ ${ }^{2}$ Singapore Botanic Gardens, 1 Cluny Road, Singapore 259569, Singapore \\ ${ }^{3}$ Plant Coversation Action Group, P.O. Box 392, Victoria, Mahé, Seychelles \\ ${ }^{4}$ Center for Plant Conservation-Bogor Botanical Gardens, Kebun Raya Indonesia, Indonesian Institute of Sciences, \\ Jl. Ir. H. Juanda No. 13 P.O. BOX 309, Bogor 16003, Indonesia
}

Correspondence should be addressed to Stephen Blackmore, s.blackmore@rbge.org.uk

Received 21 September 2011; Accepted 10 December 2011

Academic Editor: Hiroshi Tobe

Copyright ( 2012 Stephen Blackmore et al. This is an open access article distributed under the Creative Commons Attribution License, which permits unrestricted use, distribution, and reproduction in any medium, provided the original work is properly cited.

\begin{abstract}
We present a range of observations on the reproductive morphology, pollination biology and cultivation of Lodoicea maldivica (coco de mer), an endangered species with great ecological, economic and cultural importance. We review the history of study of this charismatic species. Morphological studies of the male inflorescence indicate its importance as a year-round food source to the Seychelles fauna. In situ observations suggest a number of potential biotic and abiotic pollination mechanisms including bees, flies, slugs, and geckos; trigonid bees are identified as the most likely potential natural pollinator. We outline a successful programme for ex situ pollination, germination, and cultivation of the coco de mer, highlighting the importance of temperature, humidity and light levels as well as maintaining an undisturbed environment. In combination with continued protection and monitoring, this advice may aid the future in situ and ex situ conservation of the coco de mer.
\end{abstract}

\section{Introduction}

Lodoicea maldivica (J F Gmel.) Pers. (Figure 1) is endemic to the Seychelles and is a remarkable species not only in biology, but also in ecological, economic and cultural significance. A tall, straight-trunked, dioecious palm with large fan-shaped leaves, it holds world records for the heaviest fruit of any palm (up to $45 \mathrm{~kg}$ [1]; Figure 1(e)), the heaviest seed in the plant kingdom (up to $25 \mathrm{~kg}$ [1]; Figure 1(f)), and the largest female flowers of any palm [2] (see Figures 1(b) and 1(c)).

As described in detail by Lionnet [3] and Fischer et al. [4], L. maldivica was first recorded by Garcia de Orta in 1563 as coco das Maldivas in Colóquios dos Simples e Drogas he Cousas Medicinais da Índia e assi Dalgũas Frutas Achadas Nella Onde se Tratam Algũas Cousas Tocantes a Medicina, Pratica, e Outras Cousas Boas Pera Saber [5]. At this time, its large, highly valued nuts (Figure 1(f)) could be found all around the Indian Ocean, including the Maldives, India, and
Sri Lanka, and were traded as far afield as China (where they were renowned for their supposed medicinal properties), Japan and Indonesia. Since there was no evidence regarding the source of the nuts, they were initially believed to be produced by a submarine plant species: hence the common name, coco de mer $[4,6]$. The origin of the nuts was finally traced to Praslin Island, Republic of Seychelles, by the expedition of Chevalier Marion Dufresne in 1768 [3, 4]. In 1769, Dufresne's second-in-command, Duchemin, returned to Praslin Island and exported such a large quantity of coco de mer nuts that he flooded and practically destroyed their market [3].

The ecological importance of the coco de mer is considerable. Palm forests are a key feature of the natural and secondary vegetation of the Seychelles [7] and stands of $L$. maldivica, in particular, support a unique endemic fauna including the Seychelles black parrot (Coracopsis nigra L. ssp. barclayi Newton), Seychelles bulbul (Hypsipetes crassirostris 


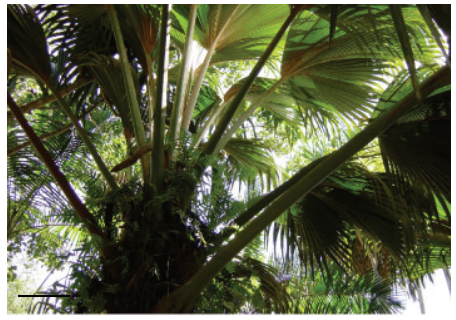

(a)

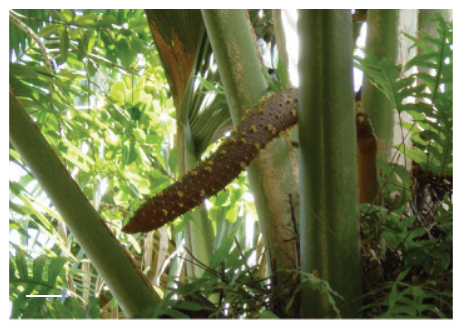

(d)

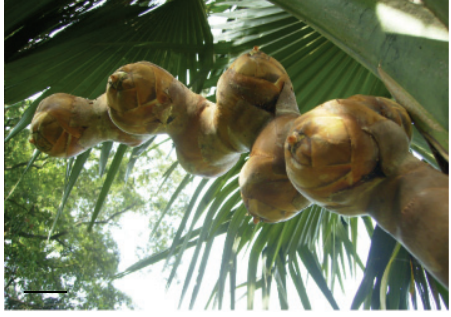

(b)

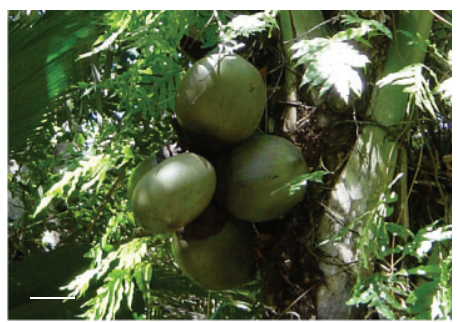

(e)

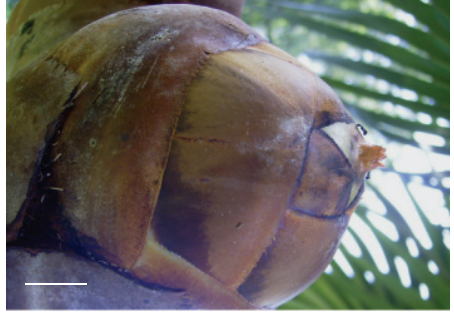

(c)

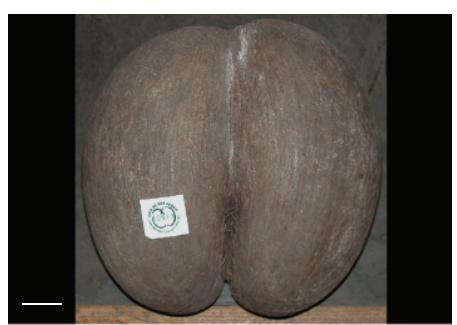

(f)

Figure 1: Morphology of Lodoicea maldivica (coco de mer). (a) Mature male tree showing axillary inflorescence, Vallée de Mai, Praslin, Republic of Seychelles, (b) detail of female inflorescence with developing fruits, Kebun Raya Indonesia, (c) female flower at anthesis, (d) male inflorescence with flowers at anthesis, (e) developing fruits, (f) mature nut sent from Vallée de Mai to the Royal Botanic Garden Edinburgh for propagation. Scale bars: (a) = approx. $1 \mathrm{~m}$; (b) = approx. $10 \mathrm{~cm}$; $(\mathrm{c})=2 \mathrm{~cm} ;(\mathrm{d})=10 \mathrm{~cm}(\mathrm{e})=10 \mathrm{~cm} ;(\mathrm{f})=10 \mathrm{~cm}$.

Newton), five species of gecko (Ailuronyx seychellensis Duméril and Bibron, A. tachyscopaeus Gerlach and Canning, A. trachygaster Duméril, Phelsuma astriata Tornier, and $P$. sundbergi Rendahl), a chameleon (Archaius tigris (Kuhl) Townsend et al.) and a snail (Pachnodus praslinus Gerlach) [6].

Economically, coco de mer nuts are the most valuable in the world (making them a prime target for poachers; see below); a value recently exemplified when one was given as a wedding gift by the government of the Seychelles to the UK heir to the throne and his wife, the Duke and Duchess of Cambridge. Long considered an antidote to various poisons [7], the suggestive form of the male inflorescence (Figure 1(d)), as well as the nuts themselves (Figure 1(f)), has spawned a wide range of commercial products such as beverages and perfumes, loosely based on the "doctrine of signatures" (and most of which have no true L. maldivica content). Since its designation as a UNESCO World Heritage Site in 1983, the L. maldivica forest of the 18 Ha Vallée de Mai Nature Reserve on Praslin Island has also become significant to the Seychelles' economy through admission fees-so much so that the funds raised are sufficient to maintain a second Seychelles World Heritage Site at Aldabra Atoll, primarily for the protection of the world's largest population of the giant tortoise, Geochelone gigantea Schweigger.

The coco de mer was traditionally useful to the inhabitants of Praslin Island, its leaves being made into thatch (sewn also with thread made from the veins of the leaves), baskets, hats and mats, trunk into furniture, crates and walking sticks, husk into rope, and nuts into utensils and vessels for water storage or liquor manufacture [8]. The indumentum of the young leaves was used for wound dressing and stuffing pillows [8], while the jelly found inside immature nuts was considered a delicacy $[7,8]$. The ripe fruits contain a tough endocarp, used to make the spots on dominoes [8]. L. maldivica remains culturally important and is known by numerous common names including the coco jumeau (twin coconut) and the highly suggestive coco indecent coco fesse and cul de negresse [3]. Seychelles legend suggests that the trees reproduce on stormy nights, when the males become mobile and "walk" to the waiting females; witnessing such an event results in death [9]. In the nineteenth century, General Gordon of Khartoum's work Eden and its Two Sacramental Trees depicted Praslin Island as the Garden of Eden and the coco de mer as its "tree of knowledge." On a more practical note, Gordon also made some of the first herbarium specimens of the species, along with a number of pertinent observations including the presence of a red, gelatinous "pollination droplet" at the female flowers and the paired arrangement of the fruits. Furthermore, he was the first to discuss its method of pollination and details of development: on an annotated drawing held the Royal Botanic Gardens, Kew (see Figure 2), he noted "fecundation takes place by bees, or by placing male flowers from baba on apex of immature nut... it bears in its $40-50$ year [sic] ... the fruit takes 7 years to ripen." Gordon was also the first person to note the dangers of overharvesting, lobbying the British government to purchase and protect parts Praslin Island and its L. maldivica forests [4].

Lodoicea maldivica is the sole species in its genus (Figure 3) and is one of six monotypic, endemic palm genera found in the archipelago [7, 10]. First formally described as a species of Cocos (C. maldivica J F Gmel.) in 1791, it was last monographed by Fauvel in 1915 [11]; his 138-page work remains the most complete. The genus was named for Louis (Lat: Lodoicus) XV of France. Lodoicea is classified, with 


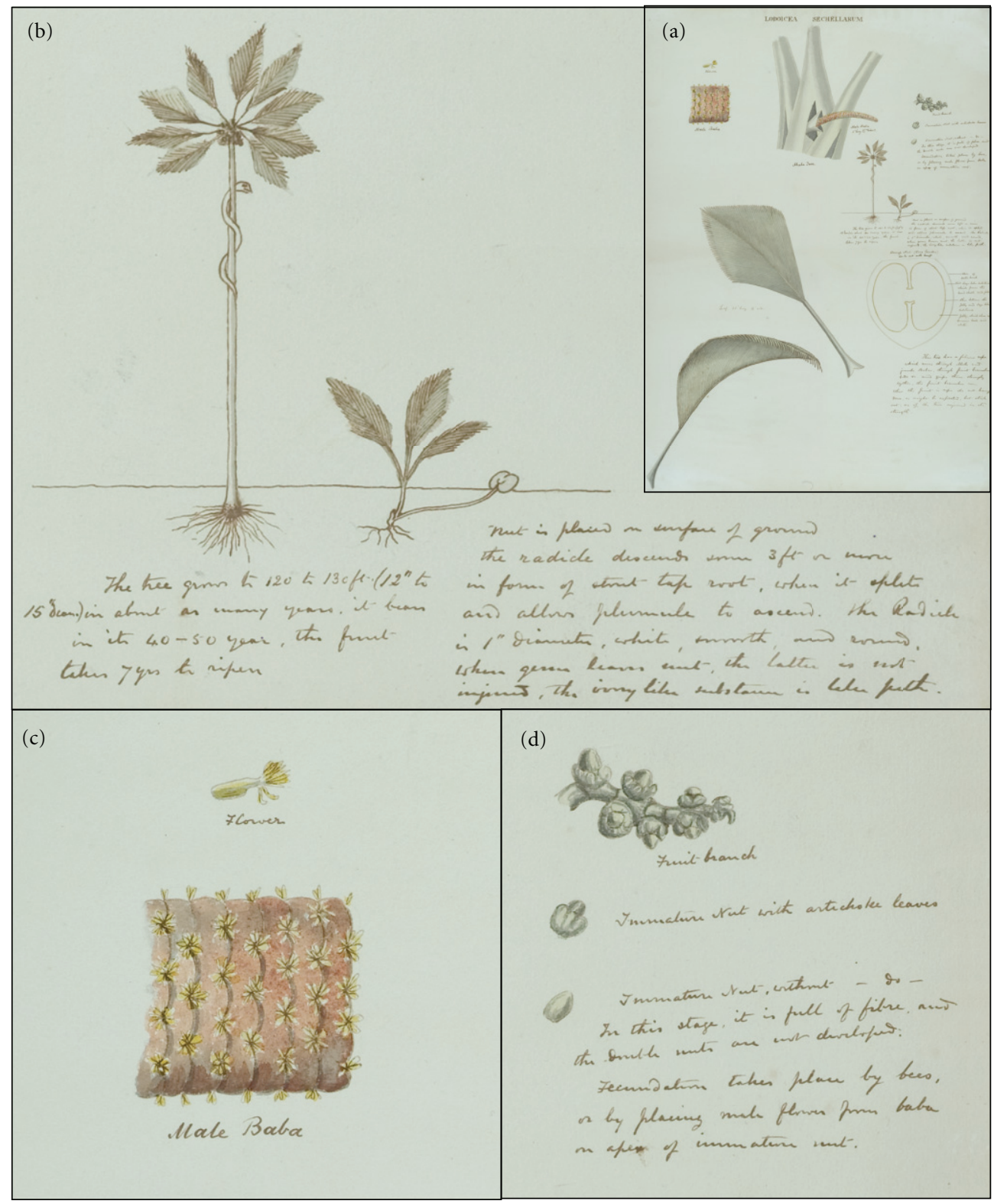

Figure 2: General Gordon of Khartoum's annotated drawings of the coco de mer, reproduced with the kind permission of the Director and the Board of Trustees, Royal Botanic Gardens, Kew. (a) Archive sheet in its entirety (the sheet measures approximately $54 \mathrm{~cm}$ by $75 \mathrm{~cm}$ ), showing leaves and male inflorescence "baba" of Lodoicea maldivica (here called "Lodoicea sechellarum"), (b) enlarged detail of his diagram and notes on the tree's stature and germination: note the snake which is thought to represent Gordon's idea that Praslin Island was the biblical Garden of Eden. Gordon's annotations read "The tree grows to 120 to $130 \mathrm{ft}$ (12" to $15^{\prime \prime}$ diam) in about as many years. It bears in its 40-50 year, the fruit takes 7 years to ripen," and "Nut is placed on surface of ground. The radicle descends some $3 \mathrm{ft}$ or more in form of stout tap-root, when it splits and allows plumule to ascend. The radicle is $1^{\prime \prime}$ diameter, white, smooth, and round. When green leaves emit, the latter is not injured, the ivory substance is like pith", (c) enlarged detail of male flower and inflorescence ("male baba"), (d) enlarged detail of fruiting branch and immature nuts. Annotations read, "Immature nut with artichoke leaves", and "Immature nut without [artichoke leaves]. In this stage it is full of fibre, and the double nuts are not developed. Fecundation takes place by bees, or by placing male flowers from baba on apex of immature nut."

three other genera (Latania Comm. ex Juss., Borassodendron Becc. and Borassus L.), in subtribe Lataniinae of tribe Borasseae in palm subfamily Coryphoideae $[2,12]$. Although phylogenetic relationships within Lataniinae are neither well resolved nor supported [12,13], it is considered most likely sister to Borassus and Borassodendron, with Latania forming the basally-branching lineage of the subtribe $[12,13]$. All Lataniinae are dioecious [2]. Morphologically, Lodoicea is perhaps the closest to Borassus, the most widespread of the four genera [14], and the only other taxon in the subtribe to produce a bilobed nut $[2,15]$, with some authors suggesting that it evolved from a Borassus-like ancestor [16]. 


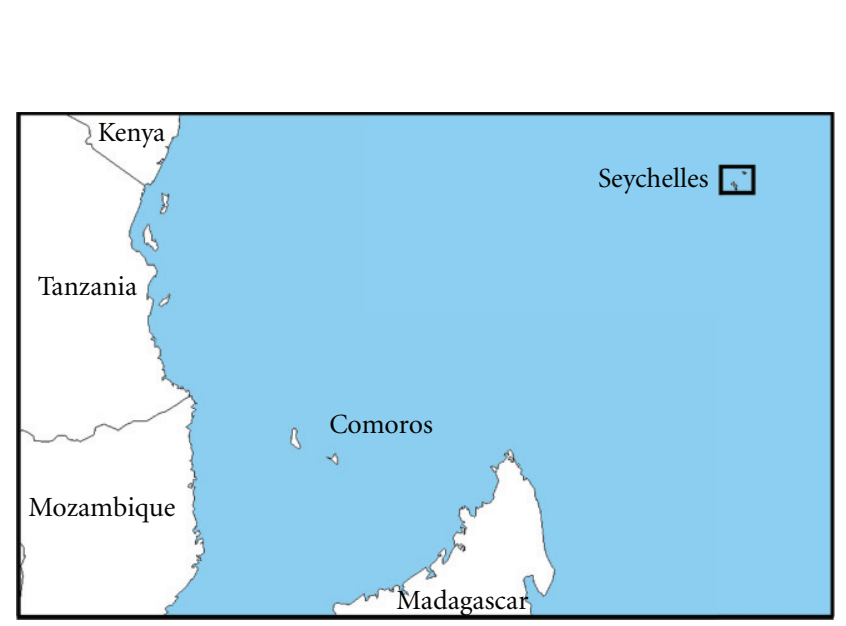

(a)

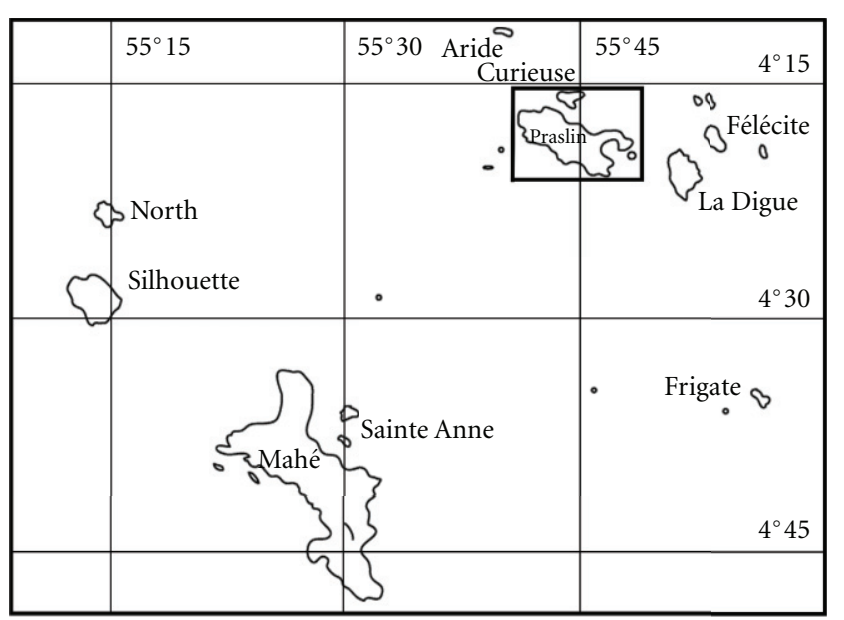

(b)

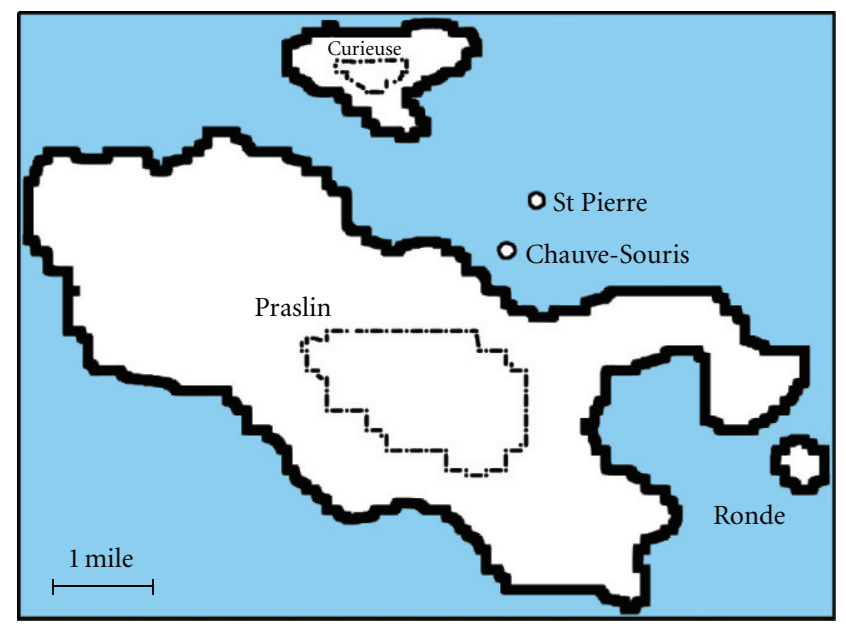

Approximate previous distribution

-i Approximate present distribution

(c)

Figure 3: Location of coco de mer populations. (a) location of Seychelles (boxed) in the Indian Ocean, (b) location of Praslin and associated islands within the Seychelles, (c) previous and present distribution of coco de mer populations.

Lodoicea maldivica is confined in the wild to the islands of Praslin and Curieuse, which together have an area of less than $5,000 \mathrm{Ha}[7,17]$. The species was once found also on St. Pierre, Chauve-Souris, and Île Ronde (Figure 3), and is, therefore, considered to be a relict species $[6,7]$. Previously, L. maldivica could be found as dense stands in valleys and within mixed-species forest on slopes and ridges; its distribution is now concentrated only in the valleys, with the slopes and ridges dominated by introduced species [6].

The largest population of L. maldivica is found on Praslin Island, where it remains locally dominant in the Vallée de Mai [10]. Two reports in the past 60 years [3, 17] have described a population of 4,000 trees including approximately equal numbers of staminate and pistillate individuals [3]. However, Savage and Ashton [18] found that male trees made up $64.3 \%$ of the flowering population, which they attributed to differences in life expectancy of male and female trees (and considered consistent with the widespread hypothesis of wind pollination, which has also recently been suggested by genetic studies [19]). By 2002, the Vallée de Mai population had been reduced to 1,162 mature trees, of which c. $55 \%$ were male [6]. Recent studies suggest totals of c. 21,000 trees on Praslin Island and a further 3,800 trees on Curieuse [4], or around 24,500 to 27,000 in the Seychelles as a whole $[19,20]$.

Lodoicea maldivica is categorised in the IUCN Red List of Threatened Species as Endangered (categories Blab $[$ ii, iii, v] + 2ab [ii, iii, v]) [21], a status to which it was recently upgraded. The major threat to the species is long-term over-exploitation of the nuts, which has had a significant detrimental effect upon natural recruitment and regeneration, thought to be affecting the demographic structure of whole stands $[20,22]$. The trees, which may live for up to 350 years [2], are estimated to take a century to reach full size and 25 years to reach reproductive age $[7,17]$, 
so this effect may be slow both to develop and to counteract. The nuts (Figure 1(f)) are harvested and sold as souvenirs, fetching prices of up to $\$ 400$ for a polished specimen $[6,20]$, or $\$ 65$ per $\mathrm{kg}$ for the kernels alone [20]. The species has been protected and the nut trade legally controlled since 1995, but poaching continues to represent a severe constraint upon regeneration in the wild $[20,23]$. Fire is another major threat which has repeatedly impacted on one small Praslin Island population, at Fond Ferdinand. These threats are compounded by the highly restricted distribution of the species, due largely to the fact that the nuts are too heavy to roll uphill, and also that they sink in water, rendering successful dispersal limited $[4,6]$.

The vegetative morphology and anatomy of L. maldivica has been described by Tomlinson [24] and Seubert [25]. Its record-breaking stature may be explained as a case of island gigantism [10], a phenomenon that has been widely discussed in terms of fauna [26-33] but little studied in plants (one notable exception being Carlquist $[34,35]$ ). In terms of reproductive structures, the female palms bear flowers on axillary spadices 1-2 $\mathrm{m}$ long and at least $5 \mathrm{~cm}$ thick. The female flowers (five to 13 per inflorescence [3]) are borne singly within a pair of broad bracts and comprise a sixlobed perianth sheathing a conical ovary with sessile stigma. The male spadices are similar in size (Lionnet [3] describes them as "the size and thickness of a man's arm") with flowers in cincinni [2], partially covered by bracts, from which the 15-18 stamens are exserted at anthesis $[2,7]$. Fertilised fruits may be up to $50 \mathrm{~cm}$ long, ovoid, and usually contain a singleseeded, bilobed (occasionally 3-6-lobed) nut [7].

Although there has recently been a growth of interest in pollination biology, particularly among the smaller palms (e.g., [36-39]), relatively little is known about that of canopy-layer palms such as L. maldivica. The most widespread assumption is that the species is predominantly anemophilous but as-yet unproven theories, both biotic and abiotic, on the pollination of the coco de mer abound. For example, Good [17] suggested the flowers are pollinated by wind and also visited by insects. Edwards et al. [16] also considered wind, and also rain, to be important in pollination, while Savage \& Ashton [18] regarded wind as the main vector, and also observed bees visiting staminate inflorescences. Fleischer-Dogley et al. [19] considered that both biotic and abiotic pollen dispersal may be important in maintaining genetic diversity. Corner [15] suggested pollination may be effected by animals such as geckos, based on the honey-like aroma of the inflorescences. Fischer et al. [4] also suggested that geckos may be involved, and indeed they have been observed visiting both male and female inflorescences. Phelsuma sundbergi, in particular, has been noted to show a strong association with male L. maldivica inflorescences [40]. Finally, Gerlach [41] reported a small dolichopodid fly as the pollinator.

Once fertilised, the fruits spend some ten months enlarging, followed by around five years ripening, during which time the endosperm solidifies and the exocarp dries and thins [7]. Fallen fruits typically do not germinate for a further six months, during which time the husk disintegrates. The process of germination, which is similar to that of related palm genera such as Latania [7], has been well documented by Bailey [7], Purocher [42] and Lionnet [3]: the base of the cotyledon itself develops into an elongated shoot, its tip comprising a cavity containing the embryo [7]. This shoot

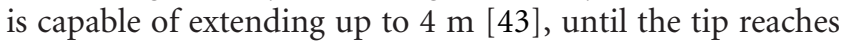
suitable soil for plant growth. At this point, the shoot curves downwards into the substrate and the embryo begins to grow, continuing to derive nutrition from the nut, through the elongated cotyledon, for two or more years until the new plant is established [9].

Despite a long history of attempts, relatively little is known about the ideal conditions for cultivation of the coco de mer. In 1890, L. maldivica was found to be the only Seychelles palm species that was impossible to cultivate at the Royal Botanic Gardens, Kew and elsewhere [44], although it was successfully cultivated at tropical localities such as Peradeniya (Sri Lanka) and Zanzibar, and is now exhibited at several tropical botanic gardens. Bailey ([7] p.18) stated vaguely that it requires "a full tropical climate ... and good growing conditions." He also noted that the ex situ success of germination likely depends on the maturity of the nut when planted. In their native habitat, L. maldivica plants are cultivated simply by lying them on a patch of moist soil [7]. It can take as long as four years before the resultant seedling is established and its connection with the nut is lost [7].

Comparable in stature and cultural significance to the cedar of Lebanon, Cedrus libani A.Rich. and the giant sequoia, Sequoiadendron giganteum (Lindl.) J. Buchholz, [3], the coco de mer is a worthy counterpart to the charismatic megafauna that today dominate conservation biology. As a "keystone" species forming dense forests on which a great variety of species depend, its conservation is crucial and depends upon a detailed understanding of the species' biology (particularly reproductive biology), ecology and cultivation. In this paper, we report a range of observations on the in situ and ex situ pollination biology, ex situ germination and cultivation of the coco de mer, data which are frequently lacking for large, Old World palms. Although they remain incomplete due to the enigmatic nature of the coco de mer, these notes may aid future in situ and ex situ conservation efforts for the species and the unique community that it sustains.

\section{Materials and Methods}

2.1. Study Sites. Materials were collected and pollinator observations made in the Vallée de Mai, Praslin Island, with supplementary collections made on Curieuse Island, both in the Republic of Seychelles (Figure 3). The Seychelles have a humid tropical climate with a strong maritime influence. Year-round average temperatures range from $27^{\circ} \mathrm{C}$ in summer to $30^{\circ} \mathrm{C}$ in spring and mean monthly rainfall ranges from $75 \mathrm{~mm}$ (summer) to $355 \mathrm{~mm}$ (January) (http://www.metoffice.gov.uk/weather/africa/eafrica_past .html). The main seasonal differences in climate are due to the direction of the prevailing winds: north western from November to April and south eastern from May to October. 
2.2. Morphology of Male Inflorescence and Flower. The morphological studies described below focus on the male inflorescence. Material of male inflorescences collected on Curieuse Island was stored in Copenhagen Solution $(70 \%$ industrial methylated spirit, $28 \%$ distilled water, $2 \%$ glycerol). Inflorescences were dissected under a Leica dissecting microscope and observed using both this and a Zeiss Axioskop compound microscope fitted with a digital camera; images were captured using Zeiss Axiovision software and edited using Adobe Photoshop Elements 5.0.

2.3. In Situ Pollination Studies. Field work to observe and capture the animal species associated with fertile male and female inflorescences took place in the Vallée de Mai, Praslin Island. This 19.5 Ha site contains over 7,000 individuals [19], which were monitored by regular observation for signs of flower maturation (male and female plants) and the presence and behaviour of potential pollinators (all observed visitors to male and female trees noted). All female trees in the Vallée de Mai were also monitored for the appearance of a pollination droplet. These observations were made by a team of in situ staff from 2003-2010, during all seasons of the year, primarily during the day with additional observations made at night. Captured animals were examined under LM and SEM for traces of pollen which would indicate their potential as pollen vectors. Any pollen grains observed on the vectors were compared with SEM images of pollen extracted directly from L. maldivica anthers. For larger animals, gut contents and faecal deposits were also analysed. SEM stubs were either uncoated (for specimens examined using variable pressure technology) or pulse sputter coated with a gold or gold/palladium (60/40) target and examined with JEOL 880, Leica Stereoscan 440, Hitachi S800, and Zeiss Supra 55VP scanning electron microscopes.

2.4. Ex Situ Pollination Studies. Artificial pollination experiments were conducted on a mature female L. maldivica tree at Kebun Raya Indonesia, with pollen from male trees at Singapore Botanic Gardens. Male flowers were harvested just prior to anthesis, packaged in a Petri dish, and sent by highspeed courier to Kebun Raya Indonesia, where mature female flowers were pollinated using a small brush. Three rounds of artificial pollination took place, in April 2004, January 2005, and April 2007, using fresh pollen each time. A further pollination took place in August 2007, using pollen stored from the April attempt.

2.5. Germination and Cultivation Studies. Ex situ germination and cultivation of L. maldivica outside of the tropics have proven notoriously difficult in the past (e.g., [44]). Three nuts were received at the Royal Botanic Garden Edinburgh from the Vallée de Mai, Seychelles, in 2003 (courtesy of the Seychelles Island Foundation), with a further nut sent in January 2005. Germination and cultivation conditions mimicked the natural environment of the Seychelles forests as closely as possible, particularly in terms of temperature, humidity and light levels.

Germination was carried out in a propagation house, in a purpose-made crate (Figure $4(\mathrm{a})$ ), lined with black polythene to ensure total darkness, placed over heated pipes, and filled with Sphagnum L. moss. The nuts were placed on the surface of the Sphagnum and left untouched. Temperatures in the house were maintained at between 19 and $33^{\circ} \mathrm{C}$ (usually $20-30^{\circ} \mathrm{C}$ ), and in the germination case between 19 and $39^{\circ} \mathrm{C}$ (usually $20-35^{\circ} \mathrm{C}$ ); relative humidity between 60 and 100\% (usually 90-100\%).

Following production of the cotyledonary shoot, the nut was gradually raised above the surface of the soil on pots, to ensure that its tip did not come into contact with the substrate and therefore the shoot continued to extend (Figure 4(c)). When the shoot was about $20 \mathrm{~cm}$ long, the nut and shoot were transferred to a purpose-built container, comprising three bottomless pots placed on top of one another to provide a depth of at least $1 \mathrm{~m}$ for root growth (Figure 4(d)). The lowest level comprised a double layer of pots to provide extra strength. The container was filled with an equal mix of peat-free compost, fine bark chippings and medium bark chippings to maintain long-term fertility, mixed with perlite, vermiculite, and charcoal. The nut and shoot were planted into a hole within the substrate, so as not to put too much pressure upon the shoot, to a depth such that the majority of the nut was above the surface, then packed around with more of the compost mix. After watering in, the nut was mulched with Sphagnum to maintain humidity, and the plant was placed in the sunniest part of the glasshouse (lowest night temperature $18^{\circ} \mathrm{C}$, daytime temperature c. $25^{\circ} \mathrm{C}$, humidity 90-100\%), and left undisturbed as far as possible. It was watered frequently and the Sphagnum replenished as necessary.

\section{Results}

3.1. Morphology of Male Inflorescence and Flower. Male trees of $L$. maldivica in the Vallée de Mai were observed to produce flowers and pollen throughout the year, with a peak of new inflorescence production around November, coincident with the onset of the monsoon season. Male individuals were found to bear up to six long-lasting inflorescences at a time, of which two to three were actively fertile (female inflorescences, while also produced year-round, were observed to be much less frequent). Our observations of one male inflorescence (Figure 5) indicate that a single rachilla contains at least 35 flowers, separated by bract scales, and that each flower contains at least 25 anthers, significantly more than reported in recent works [2]. Given that there may be as many as 200 inflorescence branches in an inflorescence, and two or more inflorescences on a tree, this suggests that each tree may produce at least 350,000 stamens in a single season. With thousands of pollen grains in each anther, as observed under the light microscope, each tree is capable of producing over a billion (US) pollen grains per year.

Each rachilla of the male inflorescence contained flowers at a range of stages of development (Figures 5(a) and 5(b)): when some flowers were at anthesis, others contained anthers entirely undifferentiated (Figure 5(c)). Likewise, pollen from this range of flowers comprised all developmental stages, from premeiosis (no microspores apparent) through the tetrad stage, to mature pollen (Figures 5(e) and 5(f)). 


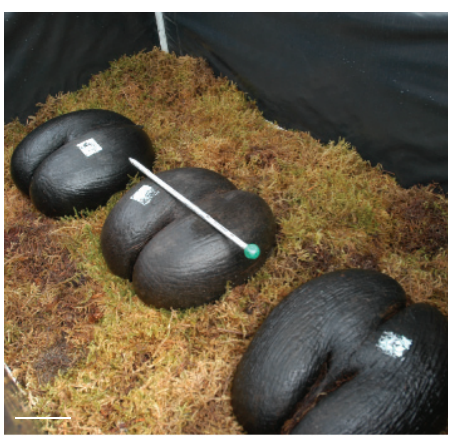

(a)

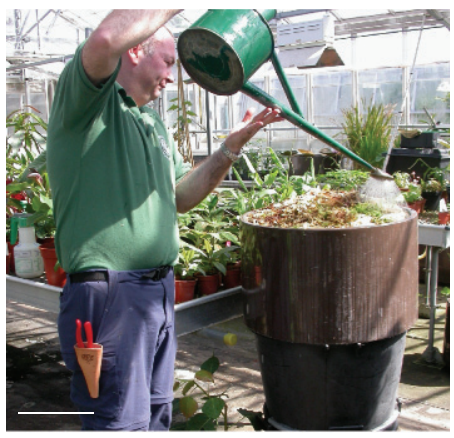

(d)

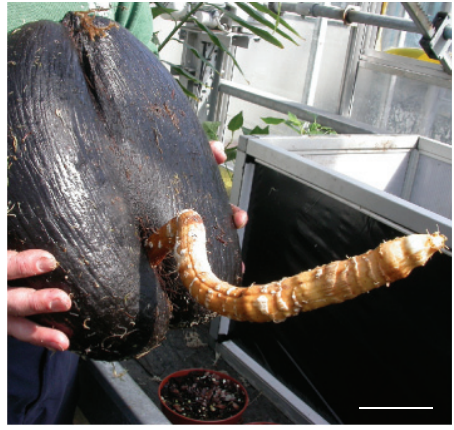

(b)

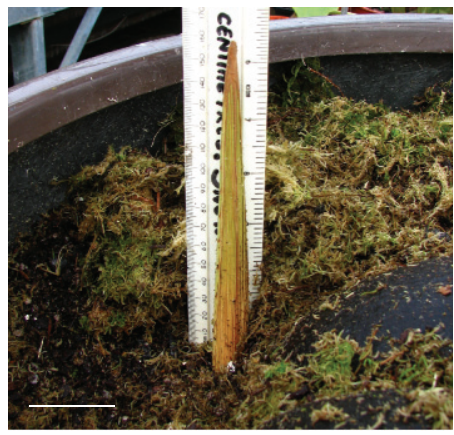

(e)

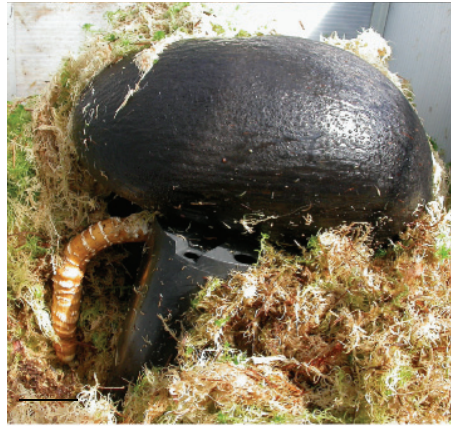

(c)

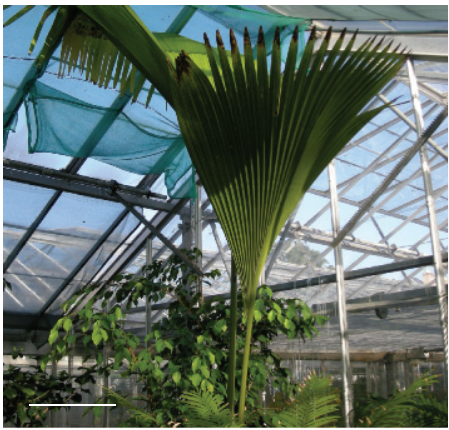

(f)

FIgURE 4: Propagation and cultivation of L. maldivica at the Royal Botanic Garden Edinburgh. (a) nuts prepared for germination in purposemade heated crate, lined with Sphagnum moss, (b) nut with cotyledonary shoot, (c) care of germinating nut by positioning on raised pots, (d) germinating nut transferred to purpose-built container, (e) radicle at c. two months after emergence, (f) young tree with two leaves, August 2009. Scale bars: $(\mathrm{a})=10 \mathrm{~cm} ;(\mathrm{b})=10 \mathrm{~cm} ;(\mathrm{c})=10 \mathrm{~cm} ;(\mathrm{d})=20 \mathrm{~cm} ;(\mathrm{e})=5 \mathrm{~cm} ;(\mathrm{f})=50 \mathrm{~cm}$.

3.2. In Situ Pollination Studies. Whilst the males of $L$. maldivica produce pollen throughout the year (Figures $1(\mathrm{~d})$, $5(\mathrm{a})$ ), the female inflorescences (Figures $1(\mathrm{~b})$ and $1(\mathrm{c})$ ) were found to be much rarer. In the Vallee de Mai, the maturation of the female flowers on an inflorescence was found to be usually sequential although on cultivated specimens at Kebun Raya Indonesia (Bogor Botanic Gardens), all female flowers observed were roughly concurrent in development. When receptive, all female flowers monitored (Figure 1(c)) were observed to exude yellowish-brown nectar. They are also reported to produce a reddish, gelatinous liquid, considered to act as a pollination droplet, although this is extremely transitory and difficult to observe. Pollination drops are most frequently associated with gymnosperms, where they may act as an attractant to pollinators or a pollen trap, which also draws the grains into the female flower.

Pollen of the coco de mer is dehisced poricidally (at least initially, but c.f. Dransfield et al. [2]) from the tips of the anther thecae (Figure 5(d)). It is coated with pollenkitt (Figure $5(\mathrm{f})$ ), by which many grains are often adhered together. The pollen grains (Figures $5(\mathrm{e})$ and $5(\mathrm{f})$ ) were found to be typical of the palm family: elliptic, monosulcate, c. $40 \mu \mathrm{m} \times 50 \mu \mathrm{m}$ in diameter, with a reticulate surface, in agreement with the observations of Ferguson et al. [45]. All pollen observed on the various potential vectors captured agreed with this description. In total, eight animal species (in six genera) were observed (and, in the case of invertebrates, captured) visiting the male inflorescence of L. maldivica in the Vallée de Mai. These species, all of which depend to some extent upon the coco de mer as a resource, may also all be considered potential pollinators of the coco de mer (Figure 6).

(i) Small stingless bees likely of the genus Trigona Jurine (Figure 6(a)). These bees were found to have large numbers of $L$. maldivica pollen grains all over their bodies, concentrated on the hind legs and the rear part of the abdomen (Figure 6(b)), where they were frequently trapped by dense hairs forming scopae. Trigona bees were also frequently seen to be attracted to the male inflorescences of trees at Singapore Botanic Gardens.

(ii) Introduced honeybees (Apis mellifera L.; Figure 6(c)). These bees also displayed dense masses of $L$. maldivica pollen in the pollen sacs (scopae) of their hind legs, also held in place by hairs (Figure 6(d)).

(iii) Dolichopodid flies of the genus Cyrturella Collin. When examined under SEM (Figure 6(e)), these appeared very similar to those identified as Ethiosciapus cf. bilobatus by Gerlach [41]. No pollen grains were found on the bodies of these flies.

(iv) White slugs (Vaginula seychellensis Fischer; Figure 6(f)), often observed to be feeding on male inflorescences-indeed this is by far the most frequent place in which they are observed. The behaviour of 


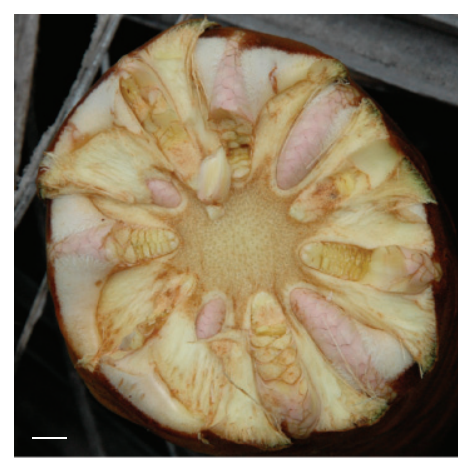

(a)

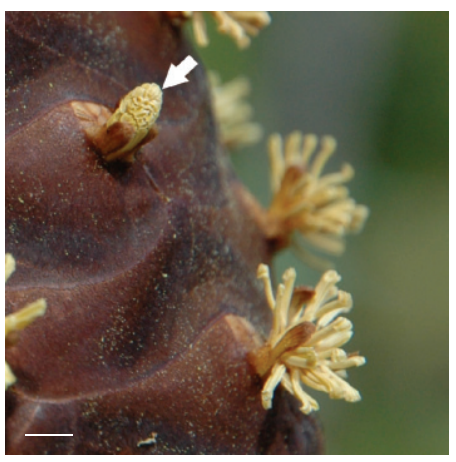

(d)

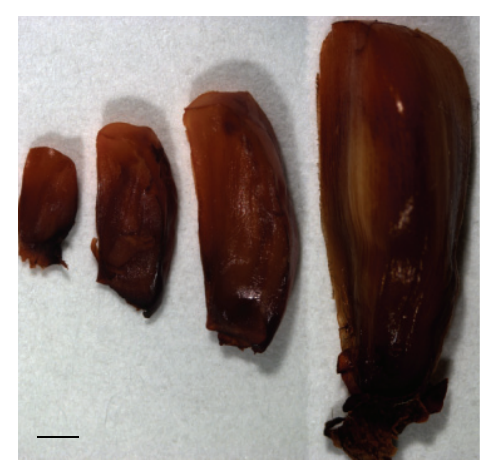

(b)

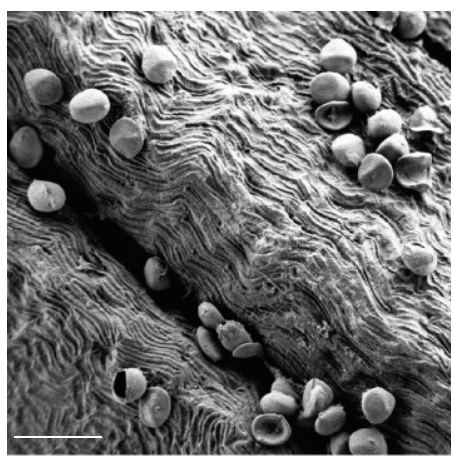

(e)

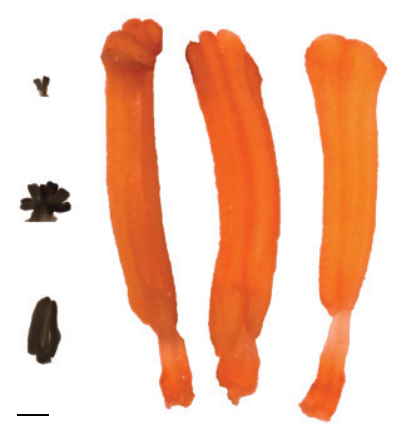

(c)

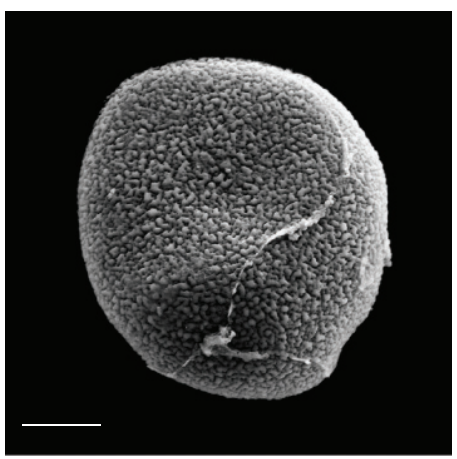

(f)

Figure 5: Inflorescence structure of male L. maldivica. (a) Transverse section of fresh male inflorescence in situ on Curieuse Island, (b) four flowers at different stages of development, dissected from the same inflorescence branch, viewed with a dissecting microscope, (c) four anthers at different stages of development, roughly approximating to the development of the flowers in Figure 5(b), viewed with dissecting and compound microscope, (d) male flowers at anthesis in situ, showing anthers with apical pore for pollen release (these are more easily seen in the slightly less open flower, arrowed), (e) pollen grains on anther surface viewed under SEM, (f) single pollen grain viewed under SEM showing reticulate surface with pollen-kitt. Scale bars: (a) $=5 \mathrm{~mm}$; (b) $=1 \mathrm{~mm}$; (c) $=500 \mu \mathrm{m}$; (d) $=5 \mathrm{~mm}$; (e) $=100 \mu \mathrm{m}$; (f) $=10 \mu \mathrm{m}$.

this species was observed to be as follows: they spend the majority of time concealed within the vegetation, emerging to feed when no other macrofauna are present, when they position themselves atop a male flower in order to consume it.

(v) Three species of brown or "bronze" geckos (Ailuronyx tachyscopaeus, A. trachygaster, and A. seychellensis, shown in Figure $6(\mathrm{~g}))$. These endemic geckos were frequently observed in association with the trees and are believed to feed on nectar and pollen from the inflorescences. No specimens were taken, but droppings (most likely from A. seychellensis) examined under SEM, consisted almost entirely of coco de mer pollen (Figure 6(h)).

(vi) Green "giant day" geckos (Phelsuma sundbergi; Figure 6(i)). This endemic, CITES-listed [46] species was frequently observed feeding both on insects visiting the male inflorescences, and on the inflorescences themselves [40, 47] and sleeping hanging from the leaves of the coco de mer; no specimens were taken and no faeces were found. Phelsuma sundbergi are highly territorial and appear to represent the dominant terrestrial macrofauna species on L. maldivica species during daylight hours. Other species, such as $V$. seychellensis, as well as other individuals of $P$. sundbergi, will avoid visiting an inflorescence when one $P$. sundbergi individual is already present, and niche partitioning between gecko species has been proposed as an important ecological factor in Seychelles palm forests [40].

Visitors to the female inflorescences included two gecko species, Ailuronyx sp. and Phelsuma sp., which were observed feeding on nectar, and the white slug Vaginula seychellensis. Numerous ants, tentatively identified as Solenopsis mameti Donisthorpe, also visited female inflorescences and consumed the nectar of plants in the Vallée de Mai, as well as at Kebun Raya Indonesia (Figure 6(j)), but it is unlikely that they are pollinators as they have never been seen foraging for pollen. Other, unidentified flying insects have also been observed around receptive female flowers (identified by the presence of a red pollination droplet) in the Vallée de Mai. Wasp species (Figure 6(k)) were also observed to be attracted to female flowers at Kebun Raya Indonesia; these are not native to the Vallée de Mai so could not be a natural pollinator, but their presence indicates that the female flowers are attractive to species of Hymenoptera. The Seychelles' endemic brown snail (Stylodonta studeriana 


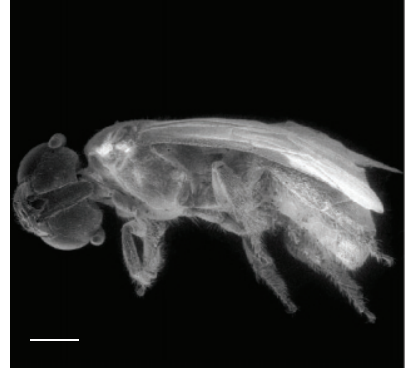

(a)

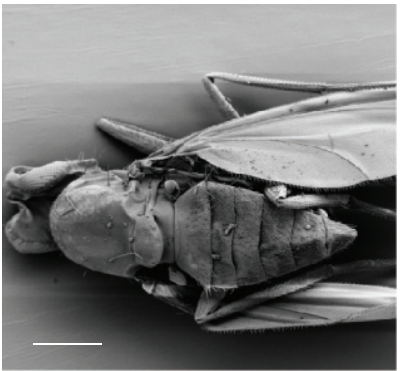

(e)

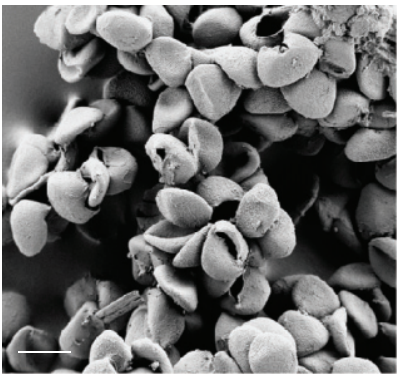

(h)

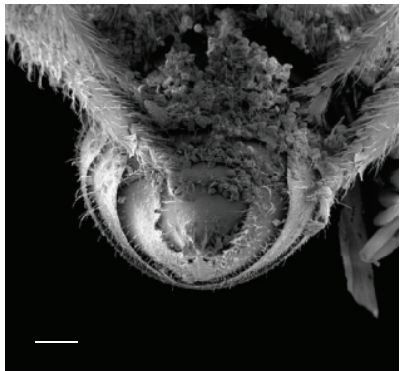

(b)

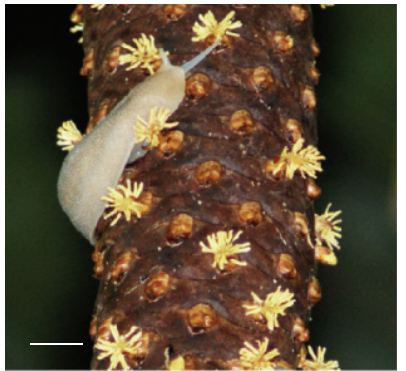

(f)

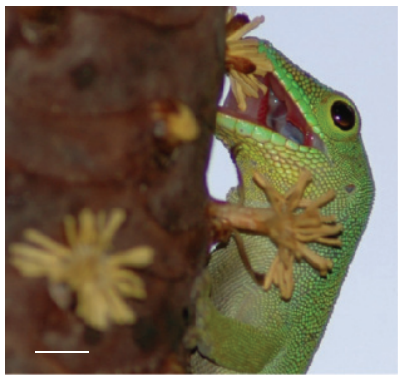

(i)

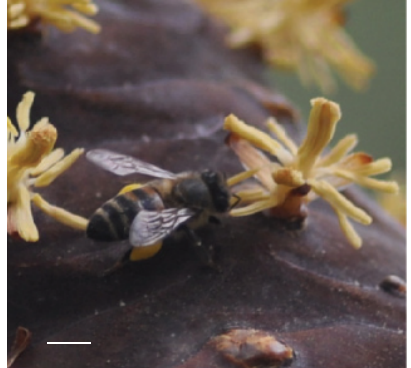

(c)

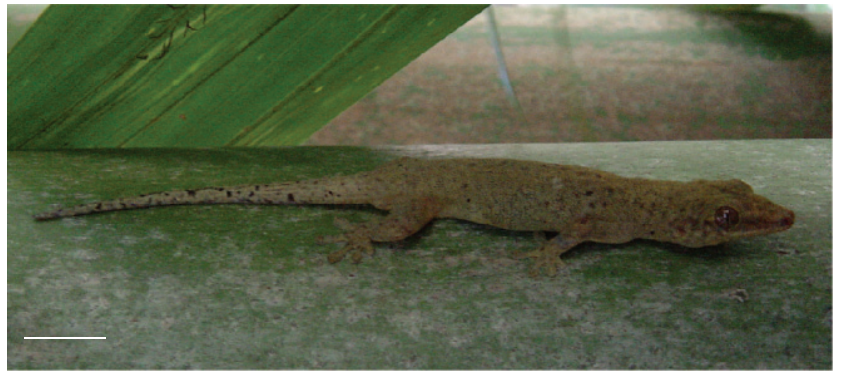

(g)

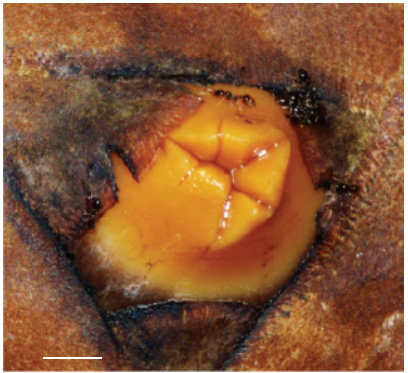

(j)

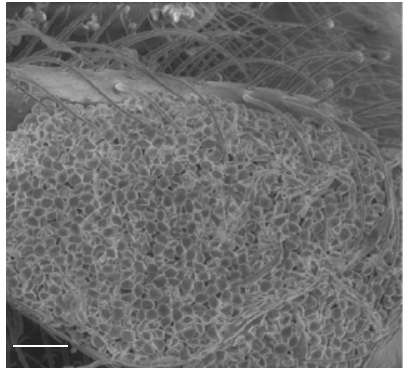

(d)

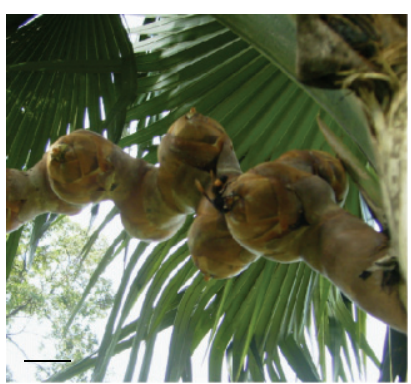

(k)

Figure 6: Candidate pollinators of coco de mer. (a) Probable Trigona sp. (stingless bee), captured in the Vallee de Mai, (b) Trigona sp., detail of abdomen and hind legs showing pollen grains of coco de mer, (c) Apis mellifera (European honeybee), visiting male inflorescence on Curieuse (note full pollen sacs on hind legs), (d) Apis mellifera, captured in the Vallée de Mai: detail of hind leg pollen sac showing pollen grains of coco de mer enclosed by hairs (e) Cyrturella sp. (dolichopodid fly), captured in the Vallée de Mai, (f) Vaginula seychellensis (white slug) feeding on male flowers of coco de mer, Vallée de Mai (g) Ailuronyx seychellensis (bronze gecko), Vallée de Mai, (h) Ailuronyx seychellensis, contents of droppings (pollen of L. maldivica) viewed under SEM, (i) Phelsuma sundbergi (giant day gecko) feeding on male flowers of coco de mer, Vallée de Mai, (j) ant, possibly Solenopsis mameti, visiting female flower of L. maldivica, Vallée de Mai, (k) wasp visiting female inflorescence of L. maldivica, Singapore Botanic Gardens. Scale bars: (a) $=500 \mu \mathrm{m} ;(\mathrm{b})=100 \mu \mathrm{m} ;(\mathrm{c})=2 \mathrm{~mm}$; $(\mathrm{d})=200 \mu \mathrm{m}$; $(\mathrm{e})=500 \mu \mathrm{m} ;(\mathrm{f})=2 \mathrm{~cm} ;(\mathrm{g})=2 \mathrm{~cm} ;(\mathrm{h})=50 \mu \mathrm{m} ;(\mathrm{i})=5 \mathrm{~mm} ;(\mathrm{j})=5 \mathrm{~mm} ;(\mathrm{k})=10 \mathrm{~cm}$.

Férussac) was also observed by General Gordon to feed on the tree but has not been observed to visit the inflorescences.

3.3. Ex Situ Pollination Studies. The first attempt at artificial pollination at Kebun Raya Indonesia involved eight flowers, of which two produced fruits. The second, involving seven flowers, also resulted in two fruits. The third pollination of eight flowers produced one fruit, and the final pollination of seven flowers (using stored pollen) was unsuccessful. These figures are comparable with the rate of successful fertilisation seen in nature: female inflorescences typically produce only one or two (occasionally up to four) fertilised fruits. The two fruits from the second pollination, in 2005, failed to survive. The remaining three fruits, two from the 2004 pollination and one from the 2007 pollination, remain on the trees in an immature state.

3.4. Germination and Cultivation Studies. Of the four nuts received at the Royal Botanic Garden Edinburgh, two successfully germinated: one received in 2003, and the sole nut received in 2005. The latter (Figure 4(b)) germinated rapidly, within six months of reception, indicating that it was a relatively mature nut which had lain on the ground in situ for some time.

The strength of the two cotyledonary shoots was markedly different, seen by their very different girth, with the 2005 shoot being approximately twice as thick as the 2003 shoot. After receiving a great deal of media attention 
(e.g., [48]), the 2003 shoot did not survive to produce a radicle or hypocotyl. A radicle emerged from the 2005 germination in September 2006, after approximately 16 months' growth (Figure 4(e)). The shoot then grew at a rate of roughly $1 \mathrm{~cm}$ per day, attaining a height of $40 \mathrm{~cm}$ by the time the leaf was beginning to unfurl in early November 2006. Since that time, the plant has grown at a rate of $c$. $5 \mathrm{~mm}$ increase in height per day, producing one leaf each year. At present, the plant has reached a height of c. $5 \mathrm{~m}$, with three fully emerged leaves and a fourth just emergent at soil level (Figure 4(f)). The second leaf was observed to be larger and stronger than the first, attaining a length of c. $3 \mathrm{~m}$, which is probably a result of the increasing maturity of the plant. A third leaf has fanned out but is not yet fully extended, at almost $2 \mathrm{~m}$ in length. Both the second and third leaves were notably slower to develop than the first, which may be due to duller weather conditions during their development. Approximately six years after germination, the original seed now appears to be hollow, indicating that the juvenile plant is now producing all its own sustenance through photosynthesis, rather than from the seed.

\section{Discussion}

An archetypal "keystone" species [49], the coco de mer lies at the centre of a complex network of interacting and interlinked organisms, which is not yet fully understood. In this paper, we discuss the fauna associated with the inflorescences, in particular the male inflorescence and pollen. The architecture of L. maldivica inflorescences has already been well described $[2,7,43]$, and instead the morphological studies presented here focus upon aspects of male floral biology and pollen production related to pollination. The morphological studies described above indicate the high reproductive potential of the male plants of $L$. maldivica: each mature plant produces billions of pollen grains per year. Despite this, the status of the species remains fragile and reproduction limited to two wild populations.

4.1. In Situ and Ex Situ Pollination Studies. Despite the general assumption that it is wind-pollinated, at least half a dozen animal species have directly been observed visiting the male flowers of $L$. maldivica. Due to the dominance of $L$. maldivica in the Vallée de Mai, and the year-round flowering of the male trees, the pollen is clearly an important food resource for the variety of vertebrate and invertebrate species know to feed upon it. Pollen is widely known to be used as a food source by beetles, bees and flies [50]; however, in the Vallée de Mai, it appears also to be the primary food source for the white slug, Vaginula seychellensis (Figure 6(f)) and bronze geckos, Ailuronyx spp. (Figures 6(g) and 6(h)). All three species of gecko found in association with the inflorescences are known to feed (although not exclusively) on L. maldivica pollen. The difficulty in observing the female pollination droplet may suggest that this is also a highly prized and rapidly consumed food source and, indeed, Phelsuma spp. have been observed licking nectar from the surface of female flowers.
Because pollination is vital to the reproduction, and, therefore, in situ conservation, of this rare and endangered species, our studies focused on determining which species (or abiotic mechanisms) are the most important natural pollinators of L. maldivica. No conclusive pollinators have so far been identified for any species of Lataniinae (although honeybees such as $A$. mellifera have been observed to visit the male flowers of Borassus madagascariensis Bojer and $B$. sambiranensis Jum. \& H.Perrier, the latter now treated as a synonym of $B$. aethiopum [51]).

To provide conclusive proof of pollination in L. maldivica, it would be necessary to observe an individual visiting the male flowers of a palm in the natural population, actively or passively collecting pollen, and transferring this to a receptive female flower. However, despite the numerous observations visitations to male flowers described above, this has not been achieved. The only organisms so far observed visiting female inflorescences (in situ) are geckos (Ailuronyx $s p$. and Phelsuma sp.) and ants. Geckos are, by their territorial nature, unlikely regularly to effect transfer of pollen between male and female flowers. Ferguson et al. [45] agree that vertebrates such as geckos are unlikely to act as pollinators. These authors also note the negative effect these creatures may have upon pollination by feeding upon bees, which may be the most successful pollinators of the coco de mer [45]. Ants have never been observed foraging on pollen at male flowers and, despite their abundance, are rarely effective pollinators of plant species [52], with any instances tending to be limited to small herbs [53].

Pollination by any of the biotic and abiotic means discussed here likely occurs occasionally. Wind pollination is known to be common in dioecious species [54]. For L. maldivica, most of the support for a theory of wind pollination derives from ex situ pollination experiments in which fertilisation is successfully achieved by placing male inflorescences above receptive female flowers, indicating effective pollen transfer through the air, as well as circumstantial genetic evidence [19]. However, such transfer differs from what would be required under natural circumstances in several ways: transfer is vertical rather than horizontal, occurs over much shorter distances than would be found between male and female trees in a forest situation, and relies upon the experimenter timing the transfer to coincide with the fertile period of the female flower. Furthermore, the pollen of L. maldivica (Figures 5(e) and 5(f)) is not typical of wind-pollinated species, being sticky with abundant pollenkitt on the surface. In addition, the female flowers do not bear the exposed, feathery or sticky stigmas commonly associated with anemophilous species, although the pollination droplet could fulfil a similar role. However, unlike gymnosperms, in which a pollination droplet does facilitate wind pollination, pollen of the coco de mer is not released into the air in large quantities, but is instead retained on the anthers for collection by foraging animals. Finally, the strong scent produced by both male and female flowers suggests adaptations for attracting pollinating insects. Thus, we consider wind to be at most a secondary means of pollination in L. maldivica.

We consider it most likely that the successful pollinator of $L$. maldivica would be a flying vector. Although several 
species of vertebrates and invertebrates have been observed visiting the inflorescences of male trees, the likelihood that sufficient numbers of animals, carrying sufficient pollen for successful pollination, could move from the inflorescence of the male tree to the much rarer female inflorescence of a different tree is highest for flying species (i.e., flying insects; birds and bats have never been observed visiting $L$. maldivica trees), especially given the height of the palms involved.

The two native animal species most likely to represent candidate pollinators of the coco de mer are, therefore, Trigona sp. bees and Cyrturella sp. flies. No species of beetle (Coleoptera) were observed in association with the inflorescences, either at night or during the day. During many years of observation, no flies of the genus Ethiosciapus have been found in association with coco de mer inflorescences (c.f. [41]). As far as is known, all dolichopodid flies (including both Cyrturella and Ethioscapus) are carnivorous, feeding on other invertebrates rather than foraging for pollen, and, therefore, are very unlikely to act as pollinators. Indeed, the relative hairlessness of Cyrturella (Figure 6(e)) compared to both species of bees observed here (Figures 6(a)-6(d)), suggests it is not adapted for pollen transfer. The large number of $L$. maldivica pollen grains adhering to the bodies of Trigona individuals (Figures 6(a) and 6(b)), whilst none have been found on the Cyrturella specimens, confirms this, and suggests that the bees are more likely to be effective pollinators - as suggested by General Gordon as long ago as the nineteenth century. The large numbers of grains also found on the introduced honeybee, Apis mellifera, indicate the possibility that this species nowadays plays a role in pollination of the coco de mer.

Previous authors have also observed bees visiting the male inflorescence of the coco de mer [45]. Although trigonid bees have not yet been observed visiting the female inflorescences, the presence of other hymenoptera (e.g., wasps observed at Singapore Botanic Gardens; Figure 6(k)) attracted to the female flowers indicates the secretion of chemicals attractive to these insects. The $L$. maldivica gynoecium is syncarpous [2], a state that is frequently related to the presence of a septal nectary, which would also indicate the likelihood of insect attractants. Corner's observation that the female flowers of the coco de mer smell of honey [15] might also indicate that they, like the male flowers, are attractive to bees. The male flowers are also reported to have a distinct scent [47].

The hypothesis of trigonid bee-pollination is in line with observations of other species in the Lataniinae: Trigona $s p$. have been observed visiting the male inflorescences of $\mathrm{Bo}$ rassodendron and Hyphaene [45] and have also been seen to visit the female inflorescence of B. borneense J. Dransf., apparently feeding on nectar [45]. To provide conclusive evidence, it would be necessary to observe a bee visiting male flowers of an L. maldivica palm in the natural population, actively or passively collecting pollen, and transferring this to a receptive female flower. This demonstration remains, at present, elusive. (Note that on Curieuse Island, the trees exist in a much more open habitat than that of the Vallée de Mai, and male and female individuals are generally at a greater distance from one another. Nevertheless, natural regeneration does occur, suggesting that successful pollination takes place and, therefore, that pollinators (or abiotic pollination mechanisms) must be present here also. Phelsuma sundbergi geckos are present on Curieuse, as are various species of bee. In this more open habitat is possible that wind also plays a part in pollination).

Outside of its natural range, artificial pollination has proven successful in fertilising L. maldivica, with five fruits produced from 23 pollinated flowers using fresh pollen, of which three survived. The numbers of fruits produced per inflorescence (one or two) were slightly fewer than is normal in natural pollination in the Seychelles (three to five per inflorescence [47]), but fertilisation was not attempted for all flowers on each inflorescence. The fertility of these fruits remains to be seen; when they are mature, attempts will be made to germinate them. Preliminary results suggest that successful ex situ pollination relies upon fresh pollen (pollen stored for four months proved unable to fertilise female flowers of coco de mer at Kebun Raya Indonesia).

4.2. Germination and Cultivation Studies. Despite initial difficulties [44], germination and cultivation of L. maldivica in botanic gardens around the world, both tropical and temperate, is now proving a successful, if time-consuming, endeavour, and a great deal has been learned about the best methods to achieve results ex situ. For instance, the critical importance of temperature, humidity and light levels for germination and survival is now understood (with slower growth observed during years with lower light availability). As observed by Bailey as long ago as 1942, the condition and maturity of the nut is also of great importance and may be difficult to ascertain when specimens are received from a distant source-hence the variable success rate seen in botanic gardens around the world. Furthermore, it is crucial to avoid tampering with germinating nuts, as the attachment of the shoot to the nut is perhaps the most fragile part of the plant at this stage and remains so until all the nutrients from the seed are expended. It will shortly be necessary to move the successfully germinated coco de mer at the Royal Botanic Garden Edinburgh into a larger pot, as its roots are becoming cramped and its largest leaf is touching the glasshouse roof and becoming scorched. Such a transfer is not without risk, in particular, the risk of detaching the plant from the nut before it is completely hollow when it may still be providing nutrients. Thus, this repotting has been delayed as long as possible and will be undertaken with the utmost care.

In the Seychelles, the traditional methodology for the cultivation of coco de mer is to plant the nut in a hole one meter deep filled with topsoil, manure (or other organic matter), and dried leaves, covered with a thin layer of soil and dry grass (to prevent the nut from being stolen) and kept moist. However, this has met with only c. $50 \%$ success. Germination in a small depression on the surface of the substrate, similar to the method used in Edinburgh, has met with almost $100 \%$ success but runs the risk of the valuable nuts being stolen. It is said that if the soil is too sandy the cotyledonary shoot will grow downwards until it rots, never returning to the surface to produce a radicle, 
and that this can be prevented by placing a flat rock in the bottom of the planting hole. An alternative, practised by the Seychelles Forestry Department, is to germinate the nuts in a cool, damp, shady spot then transfer them to a well-lit site for production of the shoot; this is most analogous to the procedure carried out at the Edinburgh Garden. Cultivation is most successful in well-drained, well-lit sites although if planted in shady sites the cotyledonary shoot is able to extend underground and produce a plant some distance from the planting site, in warmer and better-lit conditions. The more exposed the site, the more attention must be paid to watering.

The specimen at the Royal Botanic Garden Edinburgh has now survived six years from the emergence of the first shoot, has three large leaves and a fourth emergent, and is growing at an expected rate. Future growth (particularly once the seed is no longer providing nutrients) remains uncertain since it is not known, for instance, whether the species requires any mycorrhizal symbionts to survive. The sex of the Edinburgh plant has not yet been determined; and without genetic analyses, this will not be possible to determine until the first flowering, which may take 30 years or more. The plant has the potential to provide a new centrepiece for the Royal Botanic Garden Edinburgh Tropical Palm House, when the existing palm (a Sabal bermudana L. H. Bailey specimen more than 200 years old) becomes too tall. Being a slow-growing species, the coco de mer has the potential to fill this role for many decades.

\section{Acknowledgments}

The authors thank the Seychelles Islands Foundation, its Chairman, Maurice Loustau-Lalanne and Chief Executive, Frauke Fleischer-Dogley, wardens of the Vallée Atterville Cedras, Victorin Laboudallon and Marc Jean-Baptiste, and their rangers. They are grateful to Ross Bayton, Katy Beaver, Peter Edwards, Christopher Kaiser-Bunbury, Bärbel Koch and Pat Matyot for discussions. Insect identifications were undertaken by Graham Rotheray at the National Museums of Scotland. They also thank the anonymous reviewers for their helpful comments on the manuscript. Archival materials from the National Botanic Gardens, Glasnevin, Ireland, and the Royal Botanic Gardens, Kew, were provided by Matthew Jebb and Julia Buckley.

\section{References}

[1] P. B. Tomlinson, "The uniqueness of palms," Botanical Journal of the Linnean Society, vol. 151, no. 1, pp. 5-14, 2006.

[2] J. Dransfield, N. W. Uhl, C. B. Asmussen, W. J. Baker, M. M. Harley, and C. E. Lewis, Genera Palmarum: The Evolution and Classification of Palms, Royal Botanic Gardens, Kew, Richmond, UK, 2008.

[3] G. Lionnet, "The double coconut of the Seychelles," West Australian Nut and Tree Crops Association Yearbook, vol. 2, pp. 6-20, 1976.

[4] B. E. Fischer, F. Fleischer-Dogley, and A. Fischer, Coco de Mer: Myths and Eros of the Sea Coconut, A. B. Fischer, Berlin, Germany, 2008.
[5] H. J. Schlieben, "Coco de mer-die romantische Geschichte einer Palme," Natur und Museum, vol. 102, no. 8, pp. 281-291, 1972.

[6] F. Fleisher-Dogley and T. Kendle, The Conservation Status of the Coco de Mer, Lodoicea maldivica (Gmelin) Persoon: A Flagship Species, Royal Botanic Gardens, Kew, London, UK, 2002.

[7] L. H. Bailey, "Palms of the Seychelles," Gentes Herbarum, vol. 6, pp. 1-48, 1942.

[8] W. Andre and K. Beaver, "Traditional uses of endemic palms and pandans," Kapisen, no. 4, pp. 13-14, 2005.

[9] G. Lionnet, Coco de Mer: The Romance of a Palm, L'Ile Aux Images, Pailles, Mauritius, 1986.

[10] J. Procter, Vegetation of The Granitic Islands of the Seychelles, Kluwer Academic, Boston, Mass, USA, 1984.

[11] A. A. Fauvel, "Lo cocotier de mer des Iles Seychelles," Annales due Musee Colonial de Marseille, Series 3, vol. 1, pp. 169-307, 1915.

[12] C. B. Asmussen, J. Dransfield, V. Deickmann, A. S. Barfod, J. C. Pintaud, and W. J. Baker, "A new subfamily classification of the palm family (Arecaceae): evidence from plastid DNA phylogeny," Botanical Journal of the Linnean Society, vol. 151, no. 1, pp. 15-38, 2006.

[13] W. J. Baker, V. Savolainen, C. B. Asmussen-Lange et al., "Complete generic-level phylogenetic analyses of palms (Arecaceae) with comparisons of supertree and supermatrix approaches," Systematic Biology, vol. 58, no. 2, pp. 240-256, 2009.

[14] R. P. Bayton, "A revision of Borassus L. (Arecaceae)," Kew Bulletin, vol. 62, no. 4, pp. 561-586, 2007.

[15] E. J. H. Corner, The Natural History of Palms, University of California Press, Berkeley, Calif, USA, 1966.

[16] P. J. Edwards, J. Kollmann, and K. Fleischmann, "Life history evolution in Lodoicea maldivica (Arecaceae)," Nordic Journal of Botany, vol. 22, no. 2, pp. 227-237, 2002.

[17] R. Good, "The coco-de-mer of the Seychelles," Nature, vol. 167, no. 4248, pp. 518-519, 1951.

[18] A. J. P. Savage and P. S. Ashton, "The population structure of the double coconut and some other Seychelles palms," Biotropica, vol. 15, no. 1, pp. 15-25, 1983.

[19] F. Fleischer-Dogley, C. J. Kettle, P. J. Edwards, J. Ghazoul, K. Määttänen, and C. N. Kaiser-Bunbury, "Morphological and genetic differentiation in populations of the dispersallimited coco de mer (Lodoicea maldivica): implications for management and conservation," Diversity and Distributions, vol. 17, no. 2, pp. 235-243, 2011.

[20] L. Rist, C. N. Kaiser-Bunbury, F. Fleischer-Dogley, P. J. Edwards, N. Bunbury, and J. Ghazoul, "Sustainable harvesting of coco de mer, Lodoicea maldivica, in the Vallée de Mai, Seychelles," Forest Ecology and Management, vol. 260, no. 12, pp. 2224-2231, 2010.

[21] IUCN, "IUCN Red List of Threatened Species. Version 2011.2," 2011.

[22] A. J. P. Savage and P. S. Ashton, "Tourism is affecting the stand structure of the coco-de-mer," Principes, vol. 35, no. 1, pp. 4748, 1991.

[23] K. Fleischmann, P. Heritier, C. Meuwly, C. Kuffer, and P. J. Edwards, "Virtual gallery of the vegetation and flora of the Seychelles," Bulletin of the Geobotanical Institute ETH, vol. 69, pp. 57-64, 2003.

[24] P. B. Tomlinson, "Palmae," in Anatomy of the Monocotyledons II, C. R. Metcalfe, Ed., Clarendon Press, Oxford, UK, 1961.

[25] E. Seubert, "Root anatomy of palms-I. Coryphoideae," Flora, vol. 192, no. 1, pp. 81-103, 1997. 
[26] J. B. Foster, "Evolution of mammals on islands," Nature, vol. 202, no. 4929, pp. 234-235, 1964.

[27] J. de Vos, L. W. van der Hoek Ostende, and G. D. van den Bergh, Patterns in Insular Evolution of Mammals: A key to Island Palaeogeography, Springer-Verlag, Dordrecht, The Netherlands, 2007.

[28] M. V. Lomolino, "Body size of mammals on islands: the Island rule reexamined," The American Naturalist, vol. 125, no. 2, pp. 310-316, 1985.

[29] M. V. Lomolino, "Body size evolution in insular vertebrates: generality of the island rule," Journal of Biogeography, vol. 32, no. 10, pp. 1683-1699, 2005.

[30] C. R. McClain, A. G. Boyer, and G. Rosenberg, "The island rule and the evolution of body size in the deep sea," Journal of Biogeography, vol. 33, no. 9, pp. 1578-1584, 2006.

[31] S. Meiri, N. Cooper, and A. Purvis, "The island rule: made to be broken?" Proceedings of the Royal Society B, vol. 275, no. 1631, pp. 141-148, 2008.

[32] S. Meiri, T. Dayan, and D. Simberloff, "The generality of the island rule reexamined," Journal of Biogeography, vol. 33, no. 9, pp. 1571-1577, 2006.

[33] J. B. Losos and R. E. Ricklefs, "Adaptation and diversification on islands," Nature, vol. 457, no. 7231, pp. 830-836, 2009.

[34] S. Carlquist, "Island biology: we've only just begun," BioScience, vol. 22, no. 4, pp. 221-225, 1972.

[35] S. Carlquist, Island Biology, Columbia University Press, New York, NY, USA, 1974.

[36] E. J. Berry and D. L. Gorchov, "Reproductive biology of the dioecious understorey palm Chamaedorea radicalis in a Mexican cloud forest: pollination vector, flowering phenology and female fecundity," Journal of Tropical Ecology, vol. 20, no. 4, pp. 369-376, 2004.

[37] A. Otero-Arnaiz and K. Oyama, "Reproductive phenology, seed-set and pollination in Chamaedorea alternans, an understorey dioecious palm in a rain forest in Mexico," Journal of Tropical Ecology, vol. 17, no. 5, pp. 745-754, 2001.

[38] R. K. Rosa and S. Koptur, "Preliminary observations and analyses of pollination in Coccothrinax argentata: do insects play a role?" Palms, vol. 53, no. 2, pp. 75-83, 2009.

[39] L. A. Núñez-Avellaneda and R. Rojas-Robles, "Reproductive biology and pollination ecology of the milpesos palm Oenocarpus batana in the Colombian Andes," Caldasia, vol. 30, no. 1, pp. 101-125, 2008.

[40] T. Noble, N. Bunbury, C. N. Kaiser-Bunbury, and D. J. Bell, "Ecology and co-existence of two endemic day gecko (Phelsuma) species in Seychelles native palm forest," Journal of Zoology, vol. 283, no. 1, pp. 73-80, 2011.

[41] J. Gerlach, "Pollination in the coco-de-mer, Lodoicea maldivica," Palms, vol. 47, no. 3, pp. 135-138, 2003.

[42] Y. F. Purocher, "Seychelles botanical treasure: the "coco-demer" palm (Lodoicea maldivica Pers.)," La Revue Agricole del' Ile Maurice, vol. 26, no. 2, pp. 69-87, 1947.

[43] P. B. Tomlinson, The Structural Biology of Palms, Clarendon Press, Oxford, UK, 1990.

[44] W. Watson, “The coco-de-mer in cultivation," Nature, vol. 43, no. 1097 , pp. 19-20, 1890.

[45] D. K. Ferguson, A. J. Havard, and J. Dransfield, "The pollen morphology of the tribe Borasseae (Palmae: Coryphoideae)," Kew Bulletin, vol. 42, no. 2, pp. 405-422, 1987.

[46] UNEP-WCMC, "UNEP-WCMC Species Database: CITESListed Species," 2009.

[47] K. Beaver and L. Chong Seng, Vallée de Mai, SPACE, Mahé, Seychelles, 1992.
[48] C. Holden, "Random samples: the big seed," Science, vol. 301, pp. 1180-1181, 2003.

[49] R. T. Paine, "A note on trophic complexity and community stability," The American Naturalist, vol. 103, no. 929, pp. 9193, 1969.

[50] P. Bernhardt, "Anther adaptation in animal pollination," in The Anther: Form, Function and Phylogeny, W. G. D'Arcy and R. C. Keating, Eds., chapter 9, Cambridge University Press, Cambridge, UK, 1996.

[51] R. P. Bayton, C. Obunyali, and R. Ranaivojaona, "A reexamination of Borassus in Madagascar," Palms, vol. 47, no. 4, pp. 206-219, 2003.

[52] R. Peakall, S. N. Handel, and A. J. Beattie, "The evidence for, and importance of, ant pollination," in Ant-Plant Interactions, C. R. Huxley and D. F. Cutler, Eds., Oxford University Press, Oxford, UK, 1991.

[53] J. C. Hickman, "Pollination by ants: a low-energy system," Science, vol. 184, no. 4143, pp. 1290-1292, 1974.

[54] W. G. D'Arcy, Anthers and Stamens and What they Do, Cambridge University Press, Cambridge, UK, 1996. 

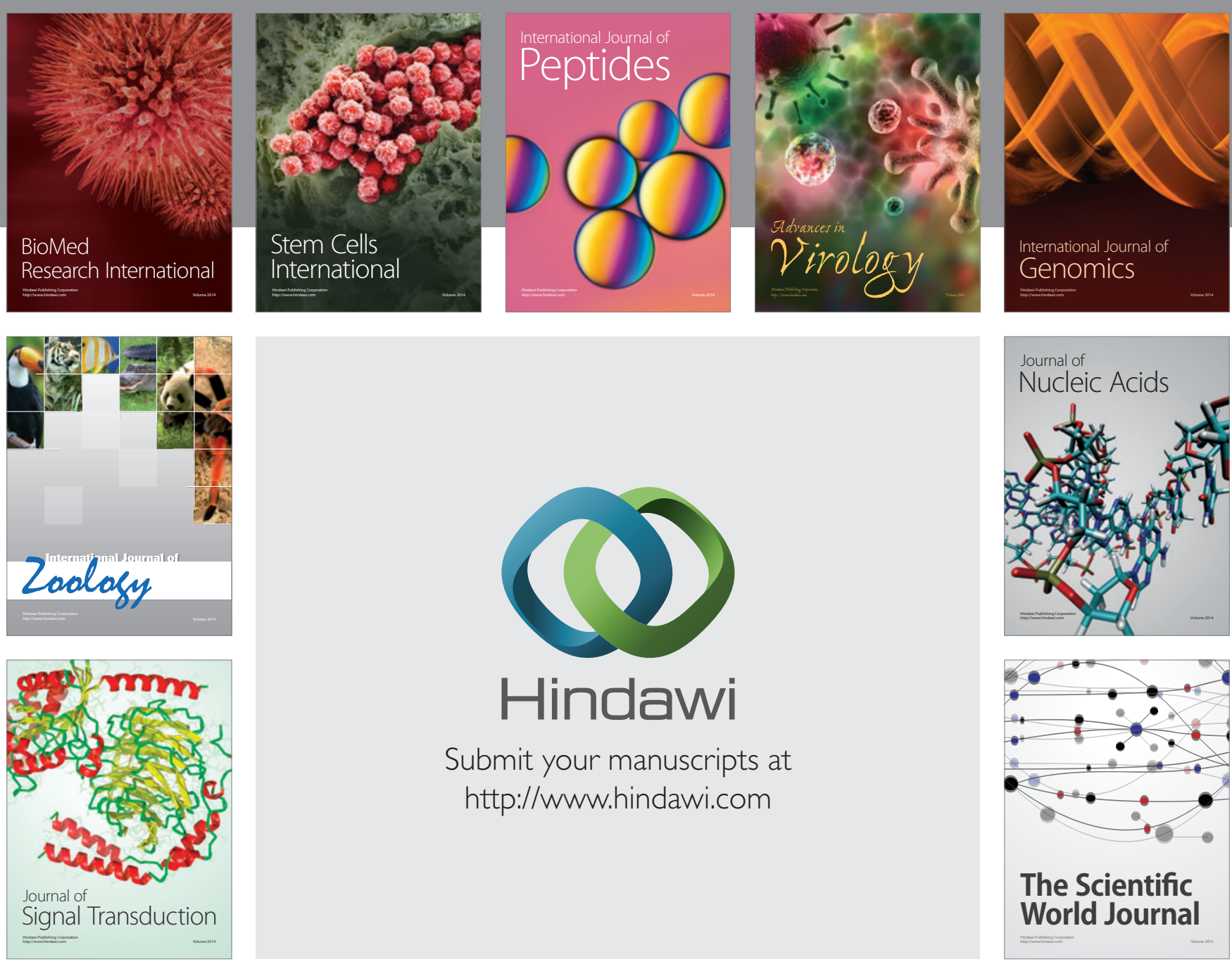

Submit your manuscripts at

http://www.hindawi.com
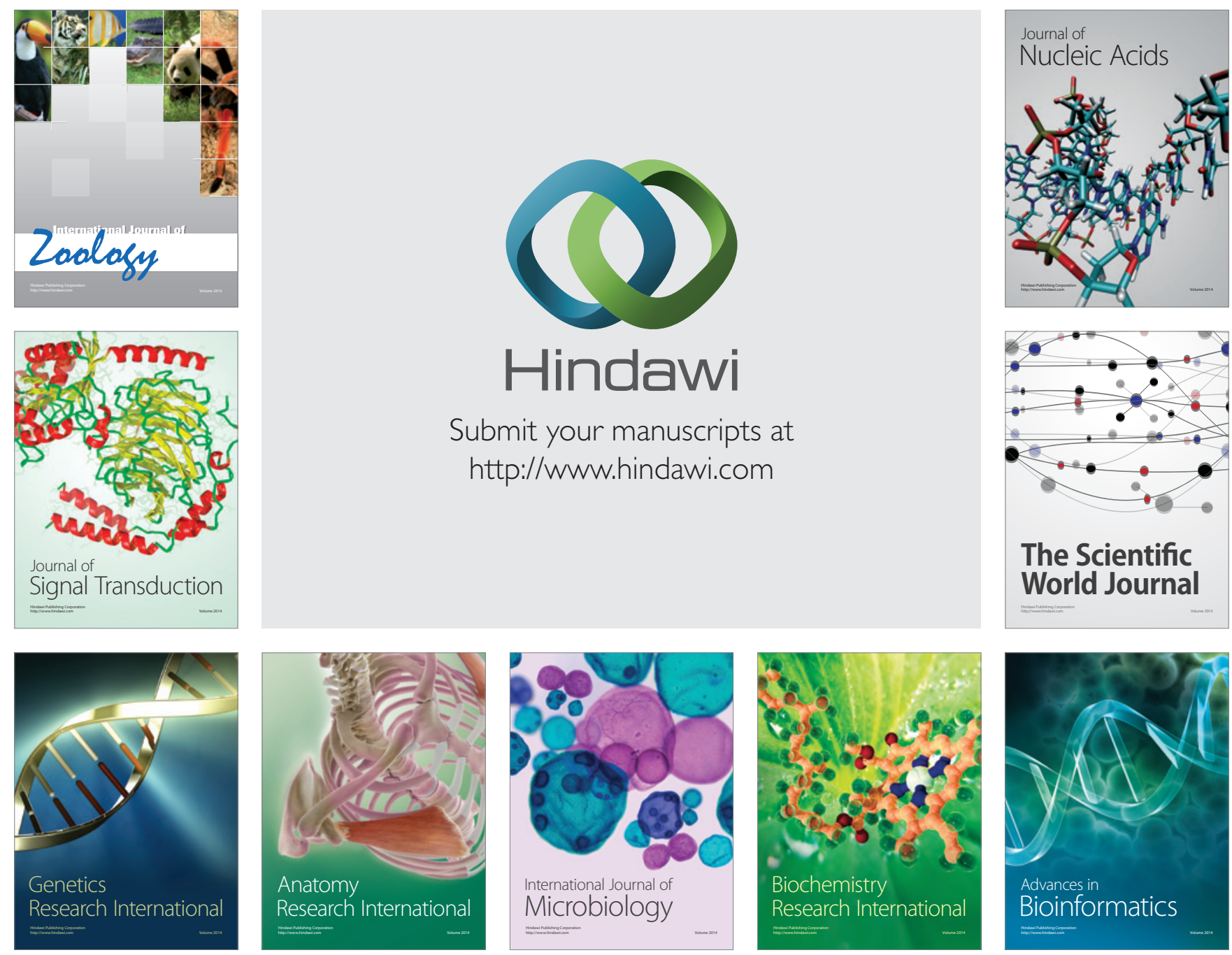

The Scientific World Journal
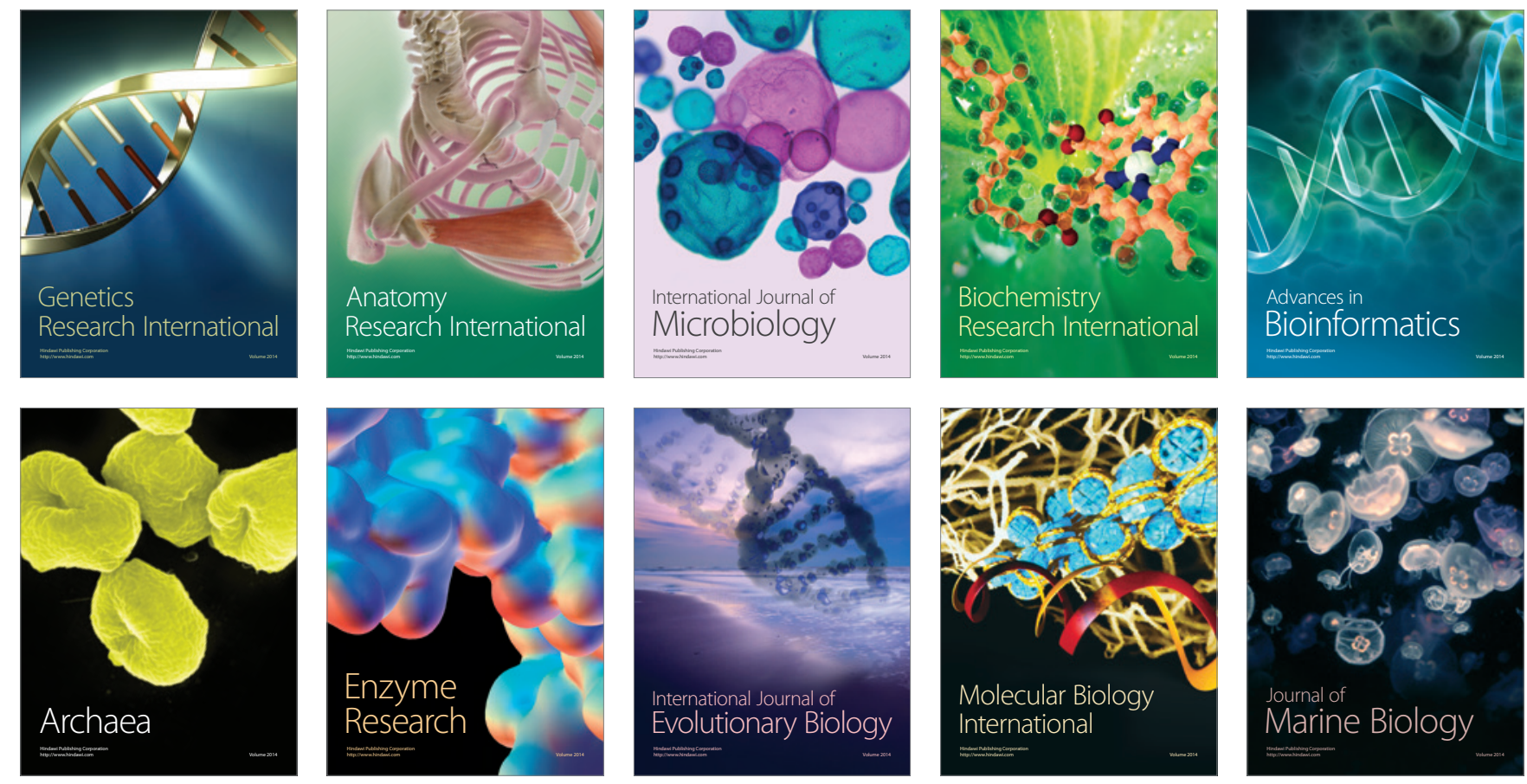